\title{
MODEL PENDIDIKAN KARAKTER RELIGIUS DALAM PERSPEKTIF SYAIH MUSTHOFA AL-GHALAYAINI
}

\author{
Muhammad Minan Nur Rohman, Ahmad Ma'ruf \\ Universitas Yudharta Pasuruan \\ minan.m@gmail.com,abmad.maruf@yudharta.ac.id
}

\begin{abstract}
Religus character education as outlined in Syaih Musthofa Al-Gblayini in the book Idhatun Nansyi'in is in accordance with what was written by Edy Suparjan, in his book entitled historical education to shape the nation's character, which is explained

Received: in the book there are educational character values which refers to the standard 100 March $21^{\text {th }} 2020$ famous figures of the world. The method of this research is library research, which means a study by studying books, manuscripts, or magazines that come from literature that is relevant to the issues raised in the study. The results of the character April 23 2020 education model in the perspective of Syaih Musthofa Al-Ghalayaini are: First, children must have sincerity. Both students must have patience. The three students must care about each other. Fourth as students must be able to start themselves, Accepted: especially others. The five students must practice their religion well. The six students May $18^{\text {th }} 2020$ as participants must keep their promises. Go as students to help one another. Eighth as students must be generous. The nine students must have a positive nature of thinking or always trying. The results of the character education model in the perspective of Syaih Musthofa Al-Ghalayaini are: First, children must have sincerity. Both students must have patience. The three students must care about each other. Fourth as students must be able to start themselves, especially others. The five students must practice their religion well. The six students as participants must keep their promises. Go as students to help one another. Eighth as students must be generous. The nine students must have a positive nature of thinking or always trying.

Keywords: Religious Character Education Model
\end{abstract}

\section{PENDAHULUAN}

Pendidikan karakter hadir sebagai solusi bagi masalah degradasi akhlak dan moralitas tersebut. Pendidikan karalter yang banyak dibincanagkan para pendidika bukanlah sebuah proses menghafal materi soal ujian dan teknik-teknik menjawabnya, namun suatu pembiasaan untuk berbuat baik yang dilakukan terus menerus agar mencapai bentuk dab kekuatan yang ideal. ${ }^{1}$ Pada dasarnya pendidikan karakter memliki hakikat yang sama dengan pendidikan moral dan akhlak yaitu memiliki tujuan untuk membentuk anak yang memiliki sifat dan prilaku yang luhur. Karakter luhur jug aperlu dibentuk dengan melalui proses pendiikan karakter mulai dari rumah yang dibentuk oleh kelurga dan lingkungan hingga pendidika yang diajarkan di sekolah. Pendidikab karakter tersebut sudah tentu dibutuhkan terutama pada usia sekolah dasar, karena jika kita membangun karakter peserta didik mulai dari dasar itu mudah sekali untuk melekat dalam diri seperti peserta didik masing-masing, yang meliputi sikap, attitude, dan tanggung jawab. ${ }^{2}$

\footnotetext{
${ }^{1}$ Masnur Muslich, Pendidikan Karakter (Menjawab Tantangan Krisis Multidimensional), (Jakarta: Bumi Aksara, 2011), hal. 81

${ }^{2}$ Barnawi dan M. Arifin, Strategi dan Kebijakan Pembelajaran: Pendidikan Karakter, (Jogjakarta: Ar-Ruzz Media, 2013) hal. 28
} 
Pendidikan karakter dan watak sangat penting, bahkan sangat mendesak dan mutlak adanya. Pendidikan karakter bertujuan untuk meningkatkan nutu penyelenggaraan dan hasil pendiikan yang mengarah pada pencapaian pembentukan karakter dan ahklak mulia peserta didik secara utuh, terpadu dan juga seimbang. ${ }^{3}$ Tujuan akhir dari proses pendidikan karakter adalah terwujudnya insan yang berilmu dan berkarakter. Karakter yang diharapkan tidak tercerabut dari budaya asli Indonesia sebagai perwujudan nasionalisme dan sarat muatan agama (religius). ${ }^{4}$

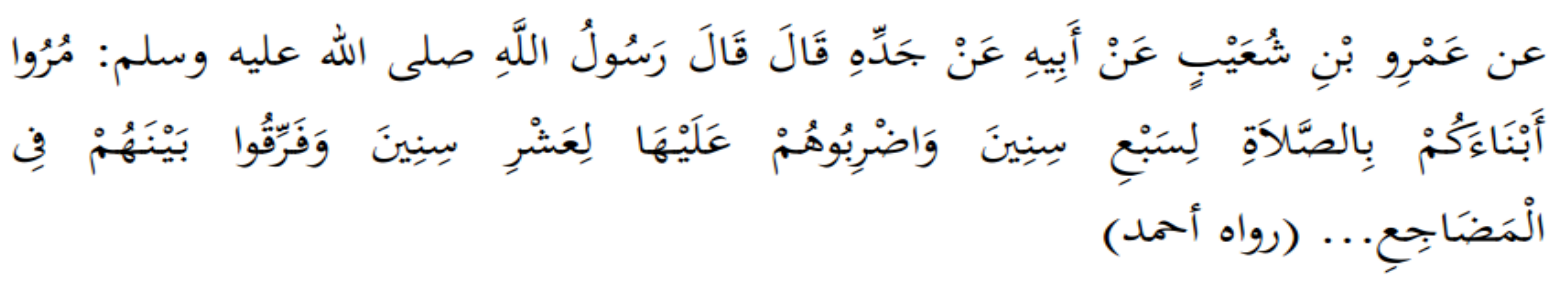

"dari 'Amr ibn Syu'Ib dari bapaknya dari kakeknya, Rasulallah Saw. Berkata: "suruhlah anakmu mendirikan sholat ketika berumur tujuh tahun dan pukullah mereka karena meninggalkannya ketika ia berumur sepuluh tahun. (pada saat itu). Pisahkanlah tempat tidur mereka. ${ }^{5}$

Pendidikan karakter tidak cukup hanya duajarkan melalui mata pembelajaran di kelas, tetapi sekolah dapat juga menerapkannya melaluyi pembiasaan yang diarahkan sebagai upaya pembudayaan pada aktivitas tertentu sehingga menjadi aktivitas yang sudah menjadi kebiasaan. ${ }^{6}$

Berkaitan dengan pernyataan tersebut, sebenarnya nilai sangat erat kaitannya dengan akhlak. Sedangkan akhlak adalah manifestasi dari kebaikan yang menyempurnakan kehidupan manusia. Pada dasarnya, akhlak atau nilai kebaikan tidak bisa terpisahkan dari keimanan. Di dalam al-Qur'an, seringkali dijumpai ayat-ayat yang menunjukkan setelah adanya kalimat "Orang-orang yang beriman”, sebagaimana pada Q.S an-Nisa' ayat 57, yang menyatakan :

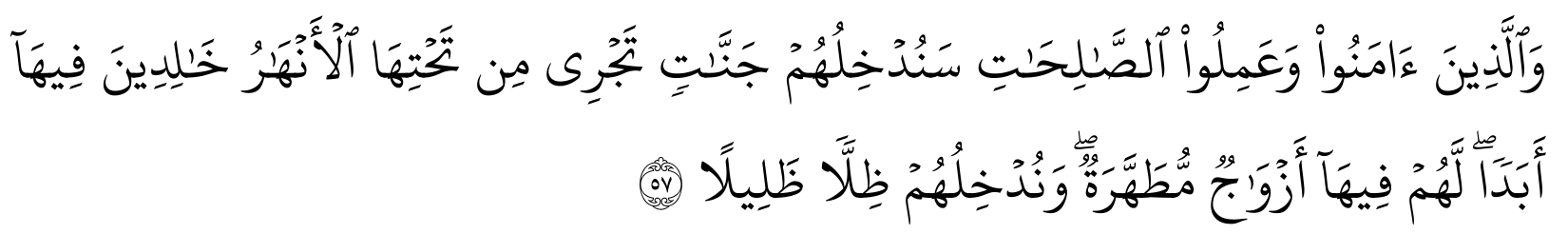

"dan orang-orang yang beriman dan mengerjakan amalan-amalan yang shaleh, kelak akan Kami masukkan mereka ke dalam surga yang di dalamnya mengalir sungai-sungai; kekal mereka di dalamnya; mereka di dalamnya mempunyai isteri-isteri yang Suci, dan Kami masukkan mereka ke tempat yang teduh lagi nyaman" (Q.S : An-Nisa' ayat 57) ${ }^{7}$

Menurut Kementrian Pendidikan Nasional (2016) Pendidikan yaitu usaha sadar serta terencana untuk mewujudkan keadaan belajar serta system evaluasi untuk peserta didik dengan aktif meningkatkan potensi dianya mempunyai kemampuan spiritual keagamaan, pengendalian diri,

\footnotetext{
${ }^{3}$ Masnur Muslich, Pendidikan Karakter (Menjawab Tantangan Krisis Multidimensional), (Jakarta: Bumi Aksara, 2011), hal. 81

${ }^{4}$ Ibid., hal. 29

5 Wiji Astuti Ningsi, Skripsi Pendidikan Karakter Religius Melalui Pembiasaan Shalat Dzubur Berjamaah Kelas V Di Sd Islam AlMadina Kota Semarang Tabun 2016/2017, hal. 6

${ }^{6}$ M. Furqan Hidayatullah, Pendidikan Karakter: Membangun Peradaban Bangsa, (Surakarta: Yuma Pustaka, 2010) hal. 52

${ }^{7}$ Departemen Agama RI, Al-Qur" an dan Terjemabnya (Bandung: CV Penerbit Diponogoro, 2008), hal. 87
} 
kepribadian, kecerdasan, akhlak mulia dan keterampilan yang di butuhkan darinya serta orangorang. 8

Nilai-nilai religius merupakan paling penting dan menjadi dasar dalam pendidikan karakter. ${ }^{9}$ Nilai ini dijadikan sebagai pangkal tolak bagi penanaman nilai-nilai lainnya. Sebagaimana di jelaskan dalam Q.S Luqman ayat 12 sebagai berikut:

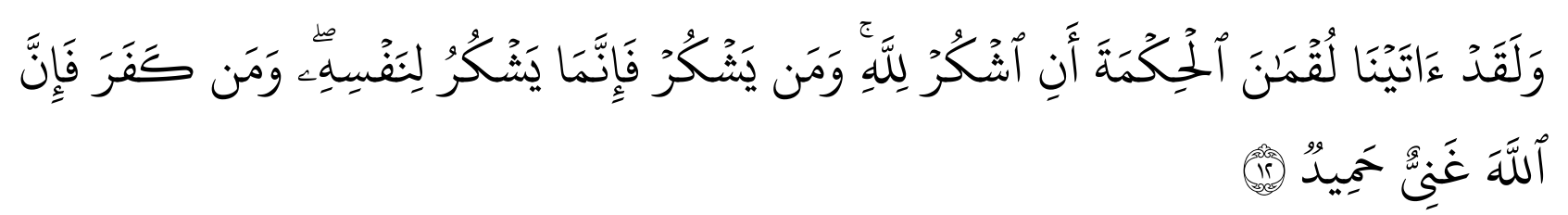

"Dan sesungguhnya telah Kami berikan hikmat kepada Luqman, yaitu: "Bersyukurlah kepada Allah. Dan barangsiapa yang bersyukur (kepada Allah), maka sesungguhnya ia bersyukur untuk dirinya sendiri; dan barangsiapa yang tidak bersyukur, maka sesungguhnya Allah Maha Kaya lagi Maha Terpuji". (Q.S. Luqman ayat 12).

Kerangka teoritis atau kerangka berfikir dibuat berdasarkan fokus penelitian, serta menggambarkan secara singkat alur penelitian yang dilakukan. Secara singkat alur penelitian yang telah dilakukan dapat digambarkan pada skema A. 1 di bawah ini:

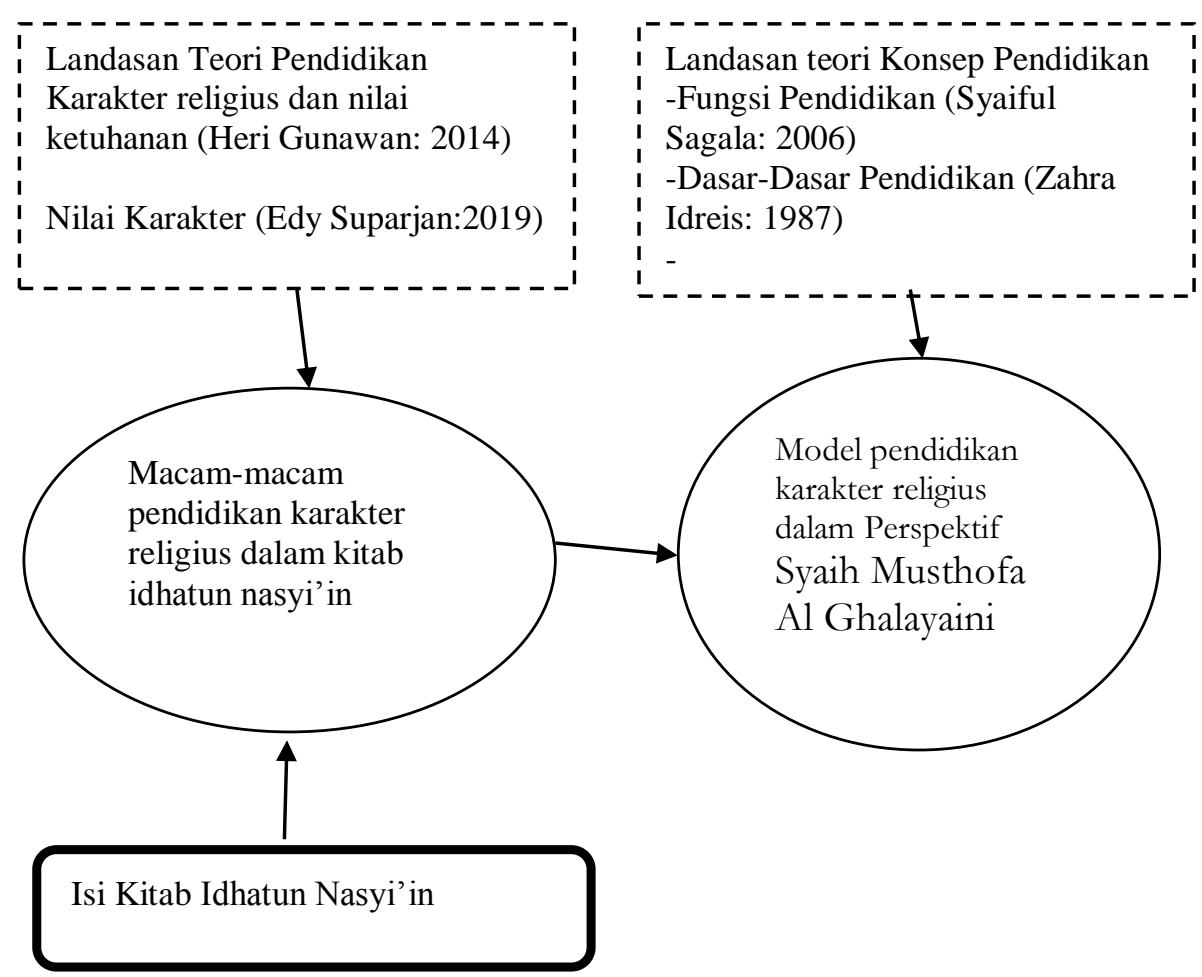

\footnotetext{
8 Permendikbud, Tentang Standard Isi Prndidikan Dasar Dan Menengah, (No.21 tahun 2016), hal. 1

9 Akhmad Muhaimin Azzel, Urgent Pendiidkan Karakter di Indonesia: Revitalisasi Pendidikan Karakter Terhadap Keberhasilan Belajar dan Kemajuan Bangsa, (Jogjakarta: Ar-Ruzz Media, 2011), hal. 30
} 


\section{METODE}

Metode penelitian ini adalah penelitian kepustakaan (Library Reseach) artinya sebuha studi dengan mengkaji buku-buku, naskah-naskah, atau majalah yang bersunber dari kepustakaan yang relevan dengan permasalahan yang diangkat dalam penelitian. semua sumber yang berasal dari bahan-bahan tertulis yang berkaitan dengan permasalahan penelitian. ${ }^{10}$ Seperti yang diungkapkan oleh Zed, studi kepustakaan (Library Reseach) adalah serangkaian kegiatan yang berkenaan dengan metode pengumpulan data pustaka, membaca, mencatata serta mengolah bahan penelitian. ${ }^{11}$ Jadi yang dimkasud studi kepustakaan (Library Reseach) adalah pengumpulan dan penelitian data dengan mencari dan membaca serta menelaah dokumen atau buku-buku yang berkenaan dengan permasalahan.

Karena jenis penelitian yang digunakan adalah penelitian kepustakaan (Library Reseach), maka peneliti dalam mengkaji pendidikan karakter religius konsep dari Syaih Musthofa Al-Ghalayaini, peneliti menggunakanbantuan buku yang peneliti ambil dari kitab karangan beliau dana juga dari buku orang lain yang menceritakan tentang kehidupan maupun pemikiran Syaih Musthofa AlGhalayaini.

Data sumber informasi yang diambil sebagai bahan analisi, dari sumber data primer dan skunder, sebab itu kualitas dan ketetapan pengambilan data tegantung pada ketajaman menyeleksi yang dipandu oleh penguasaan konsep atau teori. ${ }^{12}$ Sumber data terkait dengan subjek penelitian dari mana data diperoleh. Subjek penelitian adalah berupa teks-teks, buku-buku, novel, dan cerita pendek. Untuk analisis menggunakan metode Content Analysis atau analisis isi, yaitu sebuah teknik yang digunakan untuk menentukan atau menterjemahkan teks naskah sehingga memperoleh makna dan corak nuansa yang disajikan secara khas. ${ }^{13}$

\section{HASIL DAN PEMBAHASAN}

\section{Hasil Data}

\section{Nilai-Nilai Pendidikan karakter religius dalam kitab 'Idhatu An-Nasyi'in.}

Dalam kitab Idhatun Nasyi'in ini lebih menekankan pada aspek nilai adab, baik yang bersifat lahiriyah maupaun bersifat batiniyah. Dengan demikian, dapat kita ketahui bahwa pendidikan bukan

\footnotetext{
10 Sutrisno Hadi, Metodologi Reseach, (Yogyakarta: Yayasan Penerbitan Fakulotas Psikologi Universitas Gadjah Mada, 1980), hal. 3

${ }^{11}$ Mestika Zed, Metode Penelitian Kepustakaan, (Jakarta: Yayasan Obor Indonesia, 2004), hal. 3

12 Siswantoro, Metode Penelitian Sastra Analisis Struktur Puisi, (Yogyakarta: Rineka Cipta, 2010), hal. 70

${ }_{13}$ Anton Bekker, Metodologi Penelitian Filsafat, (Yogyakarta: PT.kanisius, 1990), hal.74
} 
hanya proses transfer ilmu pengetahuan dan keterampila akan tetapi juga pembentukan karakter pada peserta didik.

Untuik menumbukan peserta didik yang berkarakter dan bermanfaat, makan pendidikan islam juga harus mengarahkan peserta didik pada nilai-nilai pendidikan karakter yang religius. Nilai-nilai pendidikan karakter religius yang harus dimiliki peserta didik menurut Syaih Musthofa Al-Ghalayaini dalam kitab Idhatun Nasyi'in sebagai berikut:

1) Ikhlas

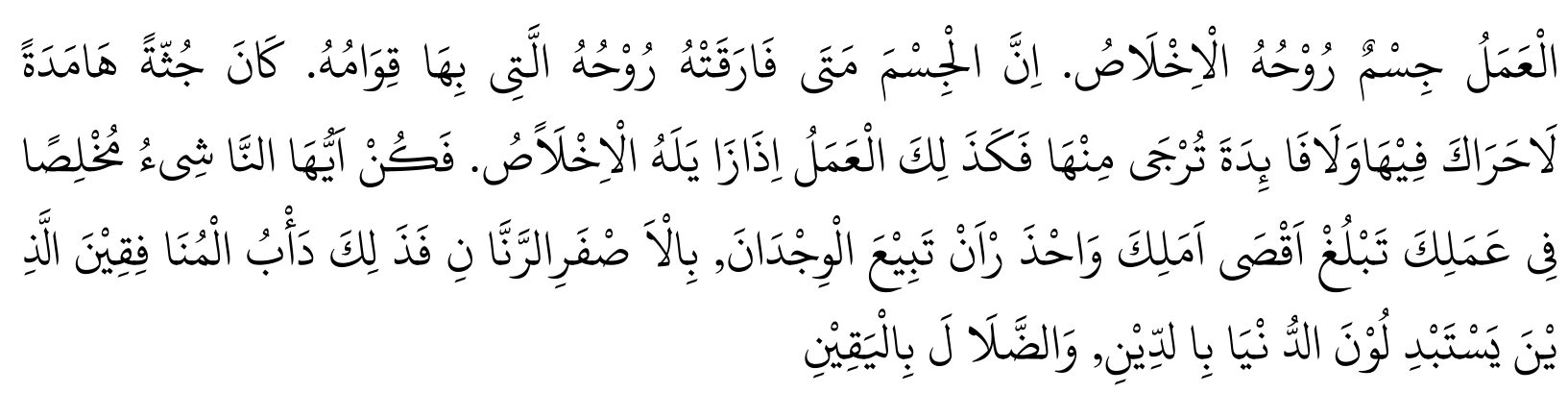

Amal perbuatan ibarat jasad, dan ruhnya adalah keikhlasan. Jasad mati manakala di tinggal oleh ruhnya. Sebab ruh yang menjadikan jasad itu hidup. Begitu juga perbuatan apabila tanpa keikhlasan. Wahai generasi muda jadilah engkau orang yang iklas dalam perjuangan, maka engkau dapat mencapai cita-citamu. Waspadalah engkau jangan sampai menukar pengorbananmu dengan emas. Sebab hal yang demikian itu merupakan tabiat orang-orang munafik, yang biasa menukar agama dengan harta kemewahan dunia dan menukar kebenaran dengan kebathilan. ${ }^{14}$

2) Sabar

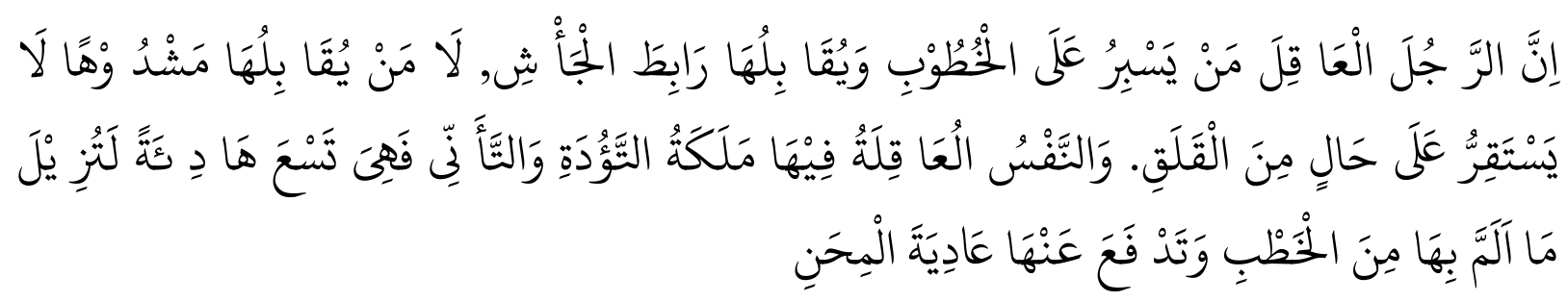

Sesungguhnya orang yang berakal ialah orang yang sabar terhadap segala macam kesulitan, juga sanggup menghadapinya dengan hati penuh kesabaran. Bukan menghadapinya dengan terkejut yang tidak menjadikan keadaan menjadi stabil dan kegelisahan. Jiwa orang yang memiliki akal, di dalamnya terdapat jiwa yang tenang dan sabar. Ia berusaha dengan tenang dalam menyingkirkan masalah yang menimpa dirinya. ${ }^{15}$

3) Kemaslahatan umum

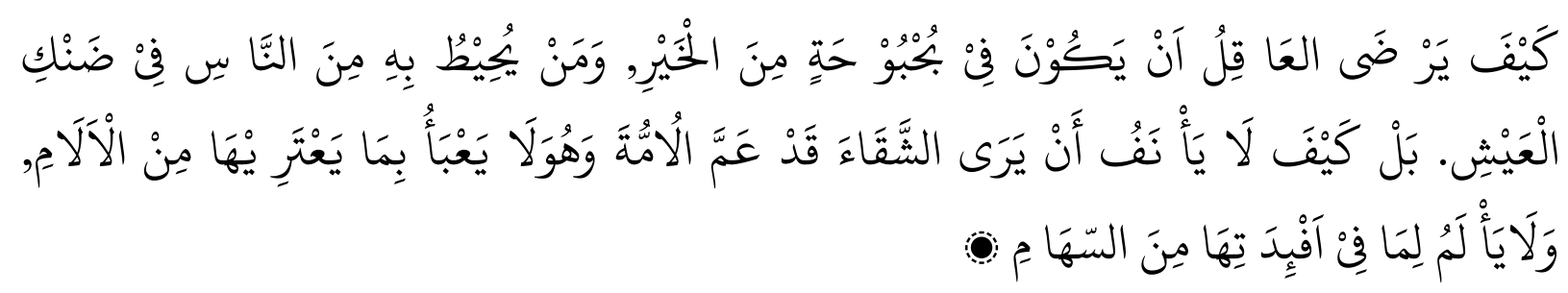

${ }^{14}$ Musthafa Al-Ghalayaini, Idhatun Nasyi’in, (Pekalongan, Maktab Rajamurah Misbah Musthofa), hal. 23

15 Ibid, hal. 13 


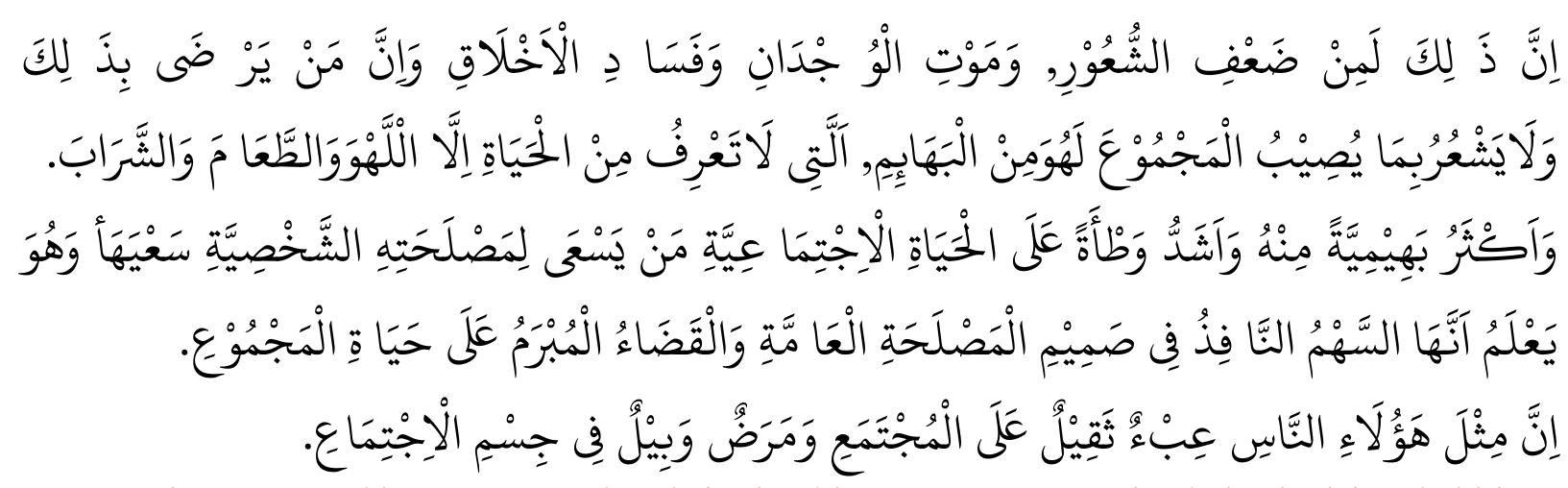

Bagaimana mungkin orang yang berakal sehat bisa merasa senang dan bahagia dalam kehidupan yang mewah, sedangkan orang-orang yang berada disekelilingnya dalam keadaan hidup sengsara? Bagaiamana dia tidak gelisah melihat kesengsaraan yang telah melanda semua lapisan umat. Sementara dia tidak memperdulikan penderitaan-penderitaaan yang tengah dirasakan umat, dan dia tidak ikut merasakan terhadap penderitaan yang mereka rasakan?

Sesungguhnya sikap seperti itu (hidup senang tanpa peduli yang lainnya hidup sengsara) adalah bagian dari kelemahan perasaan dan merupakan matinya murni serta kebobrokan moral. Sesunggunya orang yang merasa senang dengan kehidupan mereka yang lemah, sementara umat sengsara dan dia tidak peduli terhadap apa yang dirasakan umat, berarti dia termasuk binatang yang tidak mengerti arti hidup kecuali hanya untuk bersenang-senang, makan dan minum belaka.

Masih ada lagi yang lebih yang lebih besar sifat kebinatangannya dari yang telah disebutkan tadi dan lebih merusak terhadap kehidupan sodial, yaitu orang-orang yang berusaha mencari keuntungan pribadi dengan mengatasnamakan kepentingan umat. Sebenarnya dia adar bahwa yang demikian itu merugikan dan membahayakan kepentingan orang lain. ${ }^{16}$

4) Kemuliaan

Kemulian yang sesungguhnya ialah sempurna memuliahkan dirinya, sempurna keberaniannya, bersih dari pamrih dan segala sesuatunya iklas karena Allah Swt. Cukup ilmunya dan mendorong orang lain untuk mengajak memuliakan ilmu. Siapa-siapa orang yang mengumpulkan syarat-syarat ini, jelas orang itu hatinya bagus, dan akhlaknya juga pasti bagus ada dikalangan masyarakat. $^{17}$

5) Agama

Sudah semestinya badan yang bersih itu menjadi luhur/mulia, termasuk badan yang jauh dari perbuatan jelek dan bohong. Badan yang menggunakan selimut berupa ilmu dan menggunakan baju berupa agama. Datangnya agama menjadi kemuliaannya badan. Semisal tidak ada agama, perkara yang sulit tidak bisa pisah dari talinya alam ini. Artinya manusia hidup tentu begitu rumit. Semisal tidak ada agama, bengkoknya masyarakat tidak bisa lurus. Semisal tidak ada agama oranng-orang tentu tetap bertemu orang-orang yang tinggal di tanah najd, yang selalu gelap tertentu pada tempat tihamah yang jauh dari perilaku benar. Hai pemuda bijaksana!, agama yang benar itu menyempurnakan cahayanya Negara. Melakukan agamanya Allah menuntun (dia) kepada manusia. 
Hai pemuda bijaksana!, agama itu peraturan hidup dari Allah, mustahil bagi Allah memerintahkan dan membolehkan hamba dari menguasai jiwa yang menyenangkan. ${ }^{18}$

6) Dusta dan Sabar

Janganlah engkau berkata (memulai) kepada seseorang, sesungguhnya engkau adalah yang benar atau dusta, sebelum engkau melihat dalam praktik amalanya (diamalkan atau tidak). Jangan pula engkau menilai benar atau bohong terhadap suatu ucapan, sebelum engkau menilai benar atau bohong terhadap suatu ucapan, sebelum engkau mengetahui pengaruh (praktik) ucapan itu. sebab ucapan itu akan menjadi besar atau kecil nilainya, bergantung pada praktiknya. Dan ucapan itu dinilai benar jika dibuktikan dengan amalan.

Kebenaran (kejujuran) perbuatan itu merupakan hasil kerja orang-orang yang memiliki kemauan keras. Mereka itu tidak dapat dihalangi oleh siapapun dalam merealisasikan apa yang mereka ucapkan. Setiap orang sebelum menjanjikan sesuatu kepada orang lain, hendaknya dia berfikir secara mendalam. Apabila dia yakin bahwa dirinya mampu memenuhi apa yang dijanjikan, maka tidak ada larangan dia berjanji, tetapi jika sekiranya tidak mampu bahakan tidak mau memenuhi, maka sebaiknya tidak berjanji.

Wahai generasi muda, hindarilah kebiasan berdusta, sebab dusta menyebabkan retak mahkota kemuliaan. Dan hindarilah ingkar janji, sebab inkar janji menyebabkan umat menjauhimu. Apabila kalian mampu menepati janji, maka berjanjilah. Apabila kalian mampu melaksanakan pekerjaan, berkatalah. Jika tidak mampu, janganlah berjanji dan jangan mengobral perkataan agar engkau tidak dicap sebagai pembohong. ${ }^{19}$

7) Membantu orang lain (Tolong Menolong)

Jadilah kalian orang yang membantu orang lain, gemarlah berbuat baik kepada orang lain sudah tentu orang lain akan berbuat baik kepadamu. Wahai generasi muda kita tidak diciptakan kecuali agar kita slaing tolong menolong memberantas kesengsaraan yang menimpa kita dan saling bahu membahu baik dalam keadaan senanag atau sengsara dan bekerja sama mengenyahkan penderitaan yang menimpa umat. ${ }^{20}$

8) Kedermawanan

Harta kekayaan seperti halnya kekuasaan itu berfungsi sebagai pelayan bagi manusia ketika terdesak oleh kebutuhan.harta kekayaan harus di sertai dengan kedermawanan, sama sekali tidak ada manfaat dan kebaikan jika pemilikknya kikir atau boros. Sederhana atau sikap tengah-tengah bagi orang yang kaya yaitu kederwananan hal itu bisa mendatangkan kebahagian berupa harta. Dengan demikian bersikap sedang atau mengambil jalan tengah dalam segala permasalahan itu menyebabkan

18 Ibid, hal. 179

${ }^{19}$ Ibid, hal. 189

${ }^{20}$ Ibid, hal.193 
terhindar dari malapetaka. Oleh sebab itu hendaklah seseorang menginfakkan hartanya untuk kepentingan diri sendiri, keluarga dan orang-orang yang membutuhkan bantuan dengan tidak berlebihan dan tidak pula bakhil. ${ }^{21}$

9) Berusahalah dan tawakallah

Banyak sekali orang yang membiarkan persoalan dengan cara diam dan pasra. Mereka menyangka bahwa semua persolan itu telah ditentukan oleh takdir, dan Allah akan menyelesaikan masalah tersebut. Padahal, sebenarnya yang harus dilakukan adalah dia sendirilah yang menyelesaikan persoalannya, kemudian pasrah atau menyerahkan persoalannya kepada dzat yang mengaturnya.

Ada seorang laki-laki berkata kepada Nabi Saw. Wahai Rasulullah, “ saya biarkan saja unta saya itu lepas, tanpa saya ikat dan saya pasrah/tawakkal”. Mendengar perkataan tersebut, maka Nabi Saw bersabda: "ikatlah dulu untamu, lalu bertawakkallah".

Orang yang berakal adalah orang yang mampu membandingkan dua perkara yang sama-sama berbahaya, kemudia diambil yang paling ringan resiko bahayanya, karena kejelasan itu masih bias dilihat. Orang berakal itu bukanlah orang yang mampu membedakan antara baik dan buruk. Tetapi, orang berakal sebenarnya adalah orang yang dapat mengetahui yang terbaik di antara dua kejelekan. ${ }^{22}$ Sebab, pada dasarnya kejelekkan itu bertingkat-tingkat, sebagian kejelekan lebih ringan dari pada kejelekkan yang lainnya.

Wahai generasi muda, hendaklah kalian berhati-hati, jangan sampai kalian mengerjakan suatu pekerjaan secara langsung, sebelum cukup sempurna persolan kalian dan jangan sekali-kali membiarkan suatu pekerjaan dari sekian banyak pekerjaan kalian, karena pasrah sepenuhnya pada takdir yang bakal datang kemudian. Jadi, orang yang pandai adaalh orang yang menyadari betapa pentingmya suatu usaha atau ikhtiar, setelah itu baru bertawakkal.

\section{Konsep pendidikan karakter menurut syaikh Musthofa al-ghalayaini}

1) Pendidikan dalam kitab idhatun Nasyi'in

Pembahasan mengenai masalah pendidikan karakter religius menjadi sangat penting, karena pendidikan menuntun manusia untuk meraih suatu kehidupan yang jauh lenih baik. Pendidikan sangatlah dibutuhkan oleh manusia karena untuk membantu pengembangangan dirinya. Dan apabilah manusia tanpa pendidikan manusia tersebut tidak akan mencapai semua yang akan diharapkan. Dengan demikian, pendidikan menjadi sangat penting nagi setiap manusia karenaa pendidikan dan manusia merupakan suatu kesatuan yang utuh yang tidak bisa dipisahkan satu dengan yang lainnya.

\footnotetext{
${ }^{21}$ Ibid, hal. 203
}

22 Ibid, hal. 213 
Syaih Musthofa Al-Gholayaini memakai istilah tarbiyah dalam pendidikan. Dalam pandangan Syaih Musthofa Al-Gholayaini pendidikan merupakan hal yang sangat penting dan sangat berharga. Dia mengutip pendapat Syaih Musthofa Al-Gholayaini bahwa anak merupakan suatu amanah bagi kedua orang tuanya dimana hatinya masih jernih bagaikan intan yang masih belum tersentuh berbagai macam corak dan warna. Bila sejak usia dini anak sudah dibiasakan mengerjakan hal-hal yang baik, maka dia akan tumbuh dan berkembang menjadi pribadi yang baik juga. Begitu juga sebaliknya. $^{23}$

Syaih Musthofa Al-Gholayaini berkata dalam kitabnya Idhatun Nasyi'in bahwasannya:

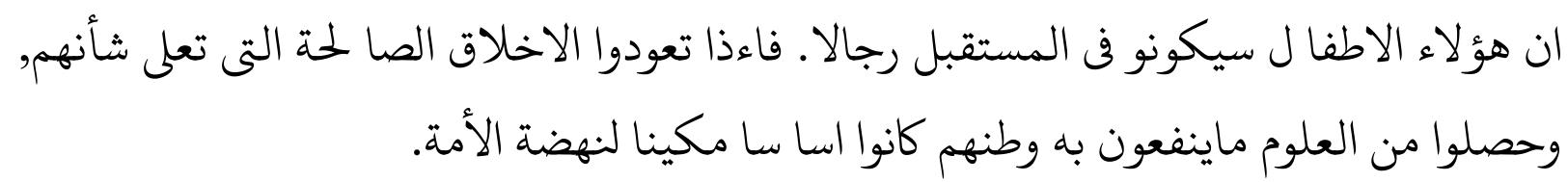

"sesungguhnya anak itu akan menjadi orang dimasa medatang, apabila anak dibiasakan berakhlak yang baik, yang dapat meninggikan drajat mereka dan berhasil mempelajari ilmu-ilmu yang bermanfaat untuk dirinya dan bermanfaat unutk Negara, maka anak-anak itu berarti menjadi dasar yang kokoh bagi kebangkitan umat". ${ }^{24}$

Anak adalah bagian dari keluarga, diamana orang tua adalah pemimpin keluarga, sebagai penanggung jawab atas keselamatan warganya di dunia maupun di akhirat dari api neraka. ${ }^{25}$

Jadi pembentukan kebiasaan seperti yang sudah disampaikan diatas menunjukkan bahwa keluarga berperan penting, karena sutau kebiasaan dari kecil itu akan dilakukannya dimasa dewa tanpa rasa berat.

Dengan demikian dapat disimpulkan bahwa pendidikan menurut Syaih Musthofa AlGholayaini adalah:

Terbiyah adalah: menanamkan akhlak yang utama, budi pekerti yang luhur serta didikan yang mulia dalam jiwa anak-anak, sejak kecil sampai ia menjadi orang yang kuasa untuk hidup dengan kemampuan usaha dan tenaganya sendiri. Semuanya itu tidak cukup ditanamkan saja, tetapi bagaikan benih yang ditancapkan di dalam bumi, perlu sekali diberi siraman dengan air, sedangkan menanamkan sesuatu dalam jiwa anak-anak yang berupa akhlak dan budi pekerti itu, bahan penyiramannya adalah memberikan petunjuk yang benar dan nasihat yang berguan, sehingga ajaran-ajaran yang mereka terima itu tidak hanya mengambang, semacam gabus diatas air, tetapi betul-betul menjadi malakah yakni meresap kalbu dan jiwa secara mendalam sekali. Manakalah sudah menjadi malakah, maka buahnya pun akan tampak bekerja untuk kepentingan tanah, Negara dan bangsa. ${ }^{26}$

23 Musthafa Al-Ghalayaini, Idhatun Nasyi'in (bimbingan Menuju Akblak Lubur) Diterjemabkan Oleh Moh. Abdai Rathomy, (Semarang: PT. Karya Toha Putra, 2002), hal. 299

24 Musthafa Al-Ghalayaini, Idhatun Nasyi'in (bimbingan Menuju Akblak. Lubur) Diterjemabkan Oleh Moh. Abdai Rathomy, (Semarang: PT. Karya Toha Putra, 2002), hal. 297

${ }^{25}$ Ahmadi Dan Ubiyati, Ilmu Pendidikan, (Jakarta: PT. Rineka Cipta), hal.117

26 Musthafa Al-Ghalayaini, Idhatun Nasyi’in (bimbingan Menuju Akblak Lubur) Diterjemabkan Oleb Moh. Abdai Rathomy, (Semarang: PT. Karya Toha Putra, 2002), hal. 315 
2) Konsep pendidikan dalam kitab Idhatun Nasyi'in

Syaih Musthofa Al-Ghalayaini menuangkan pemikirannya dalam kitab Idhatun Nasyi'in menekankan pada akhlak, etika dan kemasyarakatan. Kitab Idhatun Nasyi'in yang dirangkai oleh Syaih Musthofa Al-Ghalayaini ini berisi bimbingan untuk generasi muda muslim, agar menjadi indiviu yang bersih dari sifat-sifat yang tidak baik, tidak terpuji, tidak mempunyai akhlak mulia, dan tidak mengerti terhadap sesam muslim.

Anak didik yang masih berusia dini sekarang ini kelak dimasa mendatang akan menjadi pemimpin. Apa bila mereka membiasakan diri dengan akhlak yang baik yang dapat meninggikan drajat mereka dan berhasil mempelajari ilmu-ilmu yang bermanfaat untuk dirinya dan bermanfaat untuk Negara, maka anak-anak itu berarti menjadi dasar yang kuat bagi kebangkitan umat. Sebagaimana keterangannya Syaih Musthofa AlGhalayaini:

“anak itu wajib diberi pendidikan tentang sifat keberanian, maju, kedermawanan, kesabaran, ikhlas dalam beramal, mementingkan kemaslahatan umum diatas kepentingan pribadi, kemulian jiwa, harga diri, keberanian yang beradab, pemahaman agama yang bersih dari khurafat, peradaban yang bersih dari kerusakan, kebebasan berbicara dan bertindak yang baik dan cinta tanah air", ${ }^{27}$

Syaih Musthofa Al-Ghalayaini mengutip didalam kitabnya sifat yang harus dimiliki oleh seorang anak didik yaitu sebagai berikut:

a) Ikhlas

Syaih Musthofa Al-Ghalayaini mengatakan dalam kitabnya sebagai berikut:

"amal perbuatan itu ibarat jasad, sedangkan rohnya berupa ikhlas".

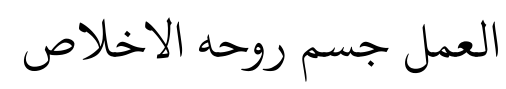

Maksudnya adalah Syaih Musthofa Al-Ghalayaini menggambarkan bahwa amal perbuatan kita ssperti tubuh, maka yang merupakan roh atau jiwa dalam tubuh itu adalah keikhlasan hati. Sedangkan kita mengetahui bahwa roh itulah yang menyebabkan hidupnya berharga bagi orang lain, bahkan itulah pengaturan hidupnya. Maka sudah jelas tubuh itu hanya sebuah mayat yang tidak berarti sama sekali.

Sering sekali kita melihat orang yang berjuang, akan tetapi kita belum melihat kesan baik atau manfaat dari usaha perjuangan mereka, bahkan sebagian besar mereka gagal, tidak dapat mencapai apa yang mereka inginkan. Karena kebayakan dari mereka berusaha dan berbuat segala sesuatu karena inign memperoleh keuntungan yang besar demi dirinya sendiri. Syaih Musthofa Al-Ghalayaini menganggap bahwa hal itu ini merupakan tindakan yang tidak mulia, bukan keutamaan bahkan bukan pula sesuatu yang patut dibanggakan

\footnotetext{
${ }^{27}$ Ibid, hal. 300
} 
karena jiwa yang mulia adalah jiwa yang ikhlas dalam berjuang tidak menuntut segalanya dari tuhan. Sebagai mana penjelasan Syaih Musthofa Al-Ghalayaini dibawah ini:

"Wahai generasi muda, jadilah engkau orang yang ikhlas dalam perjuangan, engkau pasti dapat sampai pada puncak cit-citamu. Waspadalah engkau, jangan sampai menjual atau menukar perjuanganmu dengan emas. Sebab, hal yang demikian itu merupakan tabiat orang-orang munafik, yang biasa menukar agama dengan harta kemewahan dunia dan menukar kebenaran dengan kebatilan". ${ }^{28}$

b) Kesabaran

Seseorang yang berakal adalah seseorang yang sabar menempuh segala macam kesulitan, berhatu tabah menghadapi segala macam rintangan serta berani mengorbankan jiwa untuk menyingkirkan apa saja yang menghalangi usahanya dengan penuh kesungguhan dan keberanian, bahakan tidak akan mundur selangkah pun demi mencapai cita-citanya.

Syaih Musthofa Al-Ghalayaini memberikan pengertian bahwa dalam jiwa yang berakal tertanam rasa ketenangan dan didalamnya telas meresap cara apa yang hendak dilakukan dengan teratur. Sebab setiap akan melakukan sesuatu perbuatan selalu dipikirkan secara matang serta dilakukannya dengan kesabaran dan tabah hati yang dalam.

Adapun jiwa orang bodoh itu selalu bingung setiap kali menghadapi kesulitan, meskipun itu sangat kecil. Sebab dia telah berkeyakinan, bahwa dirinya tidak sanggup menghadapinya, dia sudah merasa kalah sebelum berusaha. Dengan keyakinan tersebut tentu saja semua rintangan tidak akan menyingkir dan semakin lama kesulitan akan menjadi betumpuk-tumpuk. Itu dikarenakan didalam jiwa tidak memiliki sifat kesabaran dan ketabahan.

c) Dermawan

Harta kekayaan seperti halnya kekuasaan itu berfungsi sebagai fasilitas bagi manusia, disaat manusia terdesak oleh kebutuhan. Kedermawanan merupakan sifat yang sangat mulia, orang yang dermawan akan berusaha keras mendapatkan harta, namun tidak akan mencintai harta tersebut dengan berlebihan. Orang yang deramawan meniginginkan kekayaan untuk berbagi dengan yang lainnya. Karena didunia ini kita tidak hidup sendiri, kita pasti membutuhkan orang lain juga untuk membantu kita, begitu juga sebaliknya. Jadi initinya kita sebagai manusia yang baik dan orang muslim kita harus saling membantu satu dengan yang lainnya.

Harta kekayaan itu hanyalah suatu fasilitas untuk dapat hidup, dan harta kekayaan itu digunakan untuk membantu meringankan bebasn penderitaan orang-orang yang tidak

${ }^{28}$ Ibid, hal. 15 
mampu. Maka dari itu sifat kikir dan bakhil harus dibuang jauh-jauh dari relung kehidupan kita, karena sifat kikir dan bakhil pada akhirnya akan menghalangi untuk bisa hidup senang dan tentran dan juga akan menggiring seseorang pada kesengsaraan. Dalam alQur'an Allah Swt mengingatkan dalam firmannya yang berbunyi:

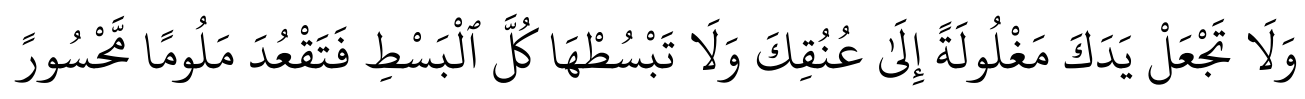

“dan janganlah kamu jadikan tanganmu terbelenggu pada lehermu dan janganlah kamu terlalu mengukurkannya karena itu kamu menjadi tercela dan menyesal”.(QS. Al-Isro':29)

Alangkah tepatnya firman Allah diatas bahwa sebagai hambanya harus menjauhi dari sifat kikir dan bahkil tersebut. Oleh karena itu mengambil sikap yang sedang mengikuti pertengahan dalam segala hal, inilah yang menyebabkan kita terhindar dari bencana. Menjadi manusia yang berakal, hendaklah memberikan nasihat atau wasiyat kepada keliarga yang menjadi tanggung jawabnya, orang-orang yang membutuhkan pertolongan dan bantuan, demikian pula untuk usaha social lainnya, yang jelas akan membawa kemanfaatan dan keuntungan di seluruh lapisan masyarakat.

Sebagaimana nasihat Syaih Musthofa Al-Ghalayaini bahwa sudah seharunya kita berpegang teguh dengan sifat kedermawanan itu. Sebagaimana penjelasan beliau sebagai berikut:

"wahai generai muda yang baik,menjauhlah dari kelompok orang-orang tersebut. Tirulah jejak orang-orang dermawan yang mulia, sebab jejak para dermawan itu adalah jalan yang jelas dan lurus. Sesungguhnya kedermawanan itu adalah sikap sedang dalam membelanjakan harta. Disitulah tempat tumpukan permohonan bantuan, itulah sifat yang diidam-idamkan setiap orang dan medan amal orang-orang mulia".

d) Kemuliaan Jiwa

Kemulian jiwa merupakan hal yang sangat penting bagi para generasi muda, kemuliaan seseorang itu tergantung pada kemulian umatnya, kelangsungan hidup seseorang itupun terletak pada kemulian umatnya, kelangsungan hidup seseorang itupun terletak dalam kehidupan umat yang dapat merasakan kenikmatan lahirnya dan batinnya, bukakn terletak pada harta yang melingpah, kekuasan maupun kekuatan.

Kemulian yang sesungguhnya itu selalu berhubungan erat dengan kejayaan yang dapat dirasakan. Kedua hal tersebutyaitu kemulian dan kejayaan itu hanya dapat dimiliki oleh orang atau bangsa yang hatinya penuh dengan keperwiraan, penuh perikemanusiaam, cukup mempunyai keberanian yang bukan dibuat-buat, suci dalam pemikiran, berbuat jujur serta menjauhi penyelewengan yang melanggar hokum agama dan Negara. Disitulah letak kemuliaan yang sejati. 
Syaih Musthofa Al-Ghalayaini memberikan nasihat kepada anak muda sebagi berikut: "wahai sekalian kaum remaja dan para pemuda serta pemudi, sebangsa dan setah air. Berpegang teguhlah dengan sifat kemulian yang sejati, sebab itulah tali penghubung antara kalian dengan tuhan, tali pengikat dan penyambung yang maha kokoh dan tidak mengkin terputuskan. Berlindunglah dalam beteng tuhan yang tidak mungkin terkalahkan dan tidak pula mungkin ditundukkan oelh muruh yang dating dari manapun. ${ }^{29}$

Tujuan pendidikan Syaih Musthofa Al-Ghalayaini yaitu: Pendidikan akhlak yang diperuntukkan oleh remaja, maka dari itu beliau memnerikan tujuan pendidikan yang ideal dan praktis, agar para remaja bisa menjadi generasi penerus yang menentukan kemajuan bangsa. Menurut Syaih Musthofa Al-Ghalayaini pendidikan sejatinya menanamkan akhlak yang utama budi pekerti yang luhur serta ajaran yang mulia dalam jiwa anak sejak dini. Karena jiwa seorang anak bagaikan lilin yang lembek yang dapat dengan mudah diukir dalam bentuk apapun, atau bagaikan kertas yang digambar dengan pensilnya. ${ }^{30}$

Syaih Musthofa Al-Ghalayainimengatakan bahwa pendidikan yang digagasnya merupakan untuk remaja, karena dalam pandanganya, sebuah bangsa tidak akan pernah maju kecuali dengan keberanian dan pengorbanan, beliau menyatakan bahwa remaja adalah generasi penerus yang menentukan kemajuan bangsanya. Jadi dapat kita simpulkan bahwa tujuan dari kitab idhatun Nasyi'in adalah agar generasi muda pada saat ini menjadi individu yang bersih dari sfiat-sifat yang tidak baik dan terpuji, akan tetapi menjadikan individu yang mempunyai akhlak yang mulia. Dengan seperti itulah maka akan terbentuk masyarakat dan bangsa yang beradab dan bermoral serta menjunjung tinggi kebenran yang sejati, sehingga mereka menjadi bangsa yang baik.

\section{PEMBAHASAN}

\section{Relevansi Pemikiran Syaih Musthofa Al-Ghalayaini Terhadap Pendidikan Karakter Religius}

Di bab ini peneliti akan membahas tentang relevansi pemikiran Syaih Musthofa Al-Ghalayaini dalam kitab Idhatun Nasyi'in dengan pemikiran para tokoh-tokoh ilmuan lainnya. Dapat di katakana bahwa analisis konsep pendidikan yang di maksud ini yang ada hubungannya dengan pengertian tentang pendidikan di dalam kitab’Idhotun Nasyi'in kesesuainnya dengan pendidikan karakter religius. Masalah pendidikan merupkan masalah yang sangat penting dalam kehidupan. Bukan saja sangat penting, bahkan masalah pendidikan itu sama sekali tidak dapat di pisahkan dari kehidupan, baik dalam kehidupan keluarga maupun dalam kehidupan bangsa dan negara. Maju mundurnya suatu bangsa sebagian besar di tentukan oleh maju mundurunya pendidikan di negara itu.

\footnotetext{
${ }^{29}$ Ibid, hal. 59

${ }^{30}$ Ibid, hal. 301
} 
Edy Suparjan mengatakan didalam bukunya bahwa pendidikan karakter sangatlah penting bagi kehidupan dimasyarkat karena Pendidikan karakter merupakan proses perkembangan yang melibatkan pengetahuan, Perasaan, dan tindakan, sebagai dasar yang kuat untuk membangun pendidikan karakter yang berhubungan dan mampu menangkap dengan baik. Dengan demikian, pendidikan karakter merupakan upaya penanaman pengetahuan, pemahaman, keterampilan, dan sikap positif siswa yang dapat mencerminkan nilai-nilai religius, kejujuran, kedisiplinan, kerja keras, toleransi, amanah, patriot, nasionalisme, mandiri, gotong royong, dan bertangung jawab. ${ }^{31}$

Sedangkan pendidikan karakter menurut Ramli yang dikutip oleh Heri Gunawan memaknai pendidikan karakter sebagai pendidikan yang memiliki esensi dan makna yang sama dengan pendidikan moral dan pendidikan akhlak. Tujuannya adalah membentuk pribadi anak, supaya menjadi manusia yang baik, warga masyarakat, dan warga Negara yang baik. ${ }^{32}$ Sedangkan Muchlas Samami memaknai pendidikan karakter sebagai proses pemberian tuntunan kepada peserta didik untuk menjadi manusai seutuhnya yang berakhlak yang baik dan berkarakter dalam dimensi hati, piker, raga, serta rasa dan karsa. $^{33}$

Sejalan dengan permasalahan diatas dalam kitab Idhatun Nasyi'in Karangan Syaih Musthofa AlGahalayaini konsep dari pada membentuk karakter anak atau peserta didik dengan Tarbiyah yaitu menanamkan akhlak yang utama, budi pekerti anak, sejak kecil dampai dia menjadi dewasa Semuanya itu tidak cukup ditanamkan saja, tetapi bagaikan benih yang ditancapkan di dalam bumi, perlu sekali diberi siraman dengan air, sedangkan menanamkan sesuatu dalam jiwa anak-anak yang berupa akhlak dan budi pekerti itu, bahan penyiramannya adalah memberikan petunjuk yang benar dan nasihat yang berguan, sehingga ajaran-ajaran yang mereka terima itu tidak hanya mengambang, semacam gabus diatas air, tetapi betul-betul menjadi malakah yakni meresap kalbu dan jiwa secara mendalam sekali. Manakalah sudah menjadi malakah, maka buahnya pun akan tampak bekerja untuk kepentingan tanah, Negara dan bangsa. ${ }^{34}$

Konsep pemikiran Syaih Musthofa Al-Ghalayaini sesuai dengan apa yang dikuti oleh Edy Suparjan. Edy Suparjan mengutip pusat kurikulum dan perbukuan kemendikbud yang berisih bahwa Pendidikan karakter memiliki tujuan yang berkaitan dengan pembinaan masyarakat yang beradab. Dalam bukunya Edy Suparjan mengatakan bahwa pendidikan karakter bertujuan untuk mengembangkan nilai-nilai yang mengikuti norma-norma pancasila. ${ }^{35}$ Jadi dengan dengan seperti itu apabila kita sudah menanamkan karakter yang baik kepada peserta didik maka akan lahirlah seorang generasi-generasi muda yang memiliki akhlak yang baik dan bisa memanusikan manusia.

\footnotetext{
${ }^{31}$ Edy Suparjan, Pendidikan Sejarah Untuk Membentuk karakter bangsa, (Yogyakarta: CV Budi Utama, 2019), hal. 19

${ }^{32}$ Heri Gunawan, Pendidikan Karakter: Konsep Dan Implementasi, (Bandung: Penerbit Alfabet, 2014), hal. 24

${ }^{33}$ Muchlis Samami dan Hariyanto, Konsep Dan Model: Pendidikan Karakter, (Bandung: PT. Remaja Rosdakarya, 2012), hal. 45

${ }^{34}$ Musthafa Al-Ghalayaini, Idhatun Nasyi'in (bimbingan Menuju Akblak Lubur) Diterjemabkan Oleh Moh. Abdai Rathomy, (Semarang: PT. Karya Toha Putra, 2002), hal. 315

${ }^{35}$ Edy Suparjan, Pendidikan Sejarah Untuk. Membentuk karakter bangsa, (Yogyakarta: CV Budi Utama, 2019), hal. 21
} 
Adapun nilai-nilai karakter religius yang harus ditanamkan menurut syaih Musthof Al-Ghalyaini didalam kitab Idhatun Nasyi'in sebagai berikut:

1. Iklas, amal perbuautan ibarat jasad, dan ruhnya adalah keikhlasan. Jasad mati manakalah di tingal oleh ruhnya. Sebab ruh yang menjadikan jasad itu hidup. ${ }^{36}$ Jadi menurut Syaih Musthofa AlGhalayaini dalam kitab Idhatun Nasyi'in apabila kita melakukan sesuatu hal maka kita harus ikhlas apabilah kita tidak ikhlas ibarat jasad tanpa roh yang artinya luarnya saja yang terlihat baik akan tetapi didalam hatinya begitu berat menjalani suatu pekerjaan yang dia lakukan.

2. Sabar, sesusungguhnya orang yang berakal ialah orang yang sabar terhadap segala macam kesulitan, juga sanggup menghadapi dengan hati penuh kesabaran. ${ }^{37}$ Jadi menurut Syaih Musthofa AlGhalayaini dalam kitab Idhatun Nasyi'in jika kiata menghadapi segala Sesutu dan sesulit apapun rintangannya kita harus sabar. Apabilah kita tidak dapat bersabar maka kita sama dengan orang yang tidak berakal (orang gila).

3. Kemaslahatan umum, Bagaimana mungkin orang yang berakal sehat bisa merasa senang dan bahagia dalam kehidupan yang mewah, sedangkan orang-orang yang berada disekelilingnya dalam keadaan hidup sengsara? Bagaiamana dia tidak gelisah me; ihat kesengsaraan yang telah melanda semua lapisan umat. Sementara dia tidak memperdulikan penderitaan-penderitaaan yang tengah dirasakan umat, dan dia tidak ikut merasakan terhadap penderitaan yang mereka rasakan? ${ }^{38}$. jadi yang dimaksud didalam kitab Idhatun Nasyi'in apabilah kita menjadi pemimpin kita harus menjadi pemimpin yang baik yang mementingkan masyarakat tidak senang dengan jabatan dan tidak mengambil hak orang lain. Karena jika kita tidak mementingkan masyarakat maka kita sama halnya dengan binatang yang hidup hanya untuk bersenang-senang.

4. Kemulian, Kemulian yang sesungguhnya ialah sempurna memuliahkan dirinya, sempurna keberaniannya, bersih dari pamrih dan segala sesuatunya iklas karena Allah Swt. ${ }^{39}$ Jadi apabila kita bisa menghargai diri kita sendiri yang artinya kita bersih dari pamrih, riya', sombong dan lain-lain, Maka kita dapat dikatakan bisa memuliakan diri kita sendiri. apabilah kita sudah daapat memuliakan diri kita sendiri maka kita dapat memuilkan orang sekitar kita.

5. Agama, Datangnya agama menjadi kemuliaannya badan. Semisal tidak ada agama, perkara yang sulit tidak bisa pisah dari talinya alam ini. Artinya manusia hidup tentu begitu rumit. ${ }^{40}$ Jadi maksud dari kutipan diatas adalah agama baju dan ilmu adalah selimut, apabilah kita menggunkan baju itu jelek maka kita juga ikut jelek akan tetapi apabila baju itu baguh maka kita juga akan terlihat bagus.

\footnotetext{
${ }^{36}$ Musthafa Al-Ghalayaini, Idhatun Nasyi’in, (Pekalongan, Maktab Rajamurah Misbah Musthofa), hal. 23

${ }^{37}$ Ibid, hal. 13

38 Ibid, hal. 79

${ }^{39}$ Ibid, hal. 80

${ }^{40}$ Ibid, hal. 179
} 
Apabila kita berbuat yang jelek maka jasad kita jutga ikut jelek, apabila kita berbuat baik maka jasad kita juga ikut baik. Dan agama juga membantu kita menyelesaikan masalah dengan baik.

6. Dusta dan Sabar, Janganlah engkau berkata (memulai) kepada seseorang, sesungguhnya engkau adalah yang benar atau dusta, sebelum engkau melihat dalam praktik amalanya (diamalkan atau tidak). Jangan pula engkau menilai benar atau bohong terhadap suatu ucapan, sebelum engkau menilai benar atau bohong terhadap suatu ucapan, sebelum engkau mengetahui pengaruh (praktik) ucapan itu. sebab ucapan itu akan menjadi besar atau kecil nilainya, bergantung pada praktiknya. Dan ucapan itu dinilai benar jika dibuktikan dengan amalan. ${ }^{41}$ Jadi kita jangan sampai kita berdusta kepada orang lain sebab dusta akan menyebabkan kepersayaan kepada orang lain akan hilang. Apabilah kita sudah berjanji maka tepatilah janji itu.

7. Membantu orang lain, Jadilah kalian orang yang membantu orang lain, gemarlah berbuat baik kepada orang lain sudah tentu orang lain akan berbuat baik kepadamu. Wahai generasi muda kita tidak diciptakan kecuali agar kita slaing tolong menolong memberantas kesengsaraan yang menimpa kita dan saling bahu membahu baik dalam keadaan senanag atau sengsara dan bekerja sama mengenyahkan penderitaan yang menimpa umat. ${ }^{42}$

8. Kedermawanan, Harta kekayaan seperti halnya kekuasaan itu berfungsi sebagai pelayan bagi manusia ketika terdesak oleh kebutuhan.harta kekayaan harus di sertai dengan kedermawanan, sama sekali tidak ada manfaat dan kebaikan jika pemilikknya kikir atau boros. ${ }^{43}$ Maksud dari kutipan diatas bahwa kita diajarkan untuk saling memberi kepada orang lain, tidak menghambur-hamburkan uang dengan hal yang tidak perlu karena banyak sekali orang diluar sana yang masih membutuhkan pemberian dari kita.

9. Berusahalah dan tawakallah, Banyak sekali orang yang membiarkan persoalan dengan cara diam dan pasra. Mereka menyangka bahwa semua persolan itu telah ditentukan oleh takdir, dan Allah akan menyelesaikan masalah tersebut. Padahal, sebenarnya yang harus dilakukan adalah dia sendirilah yang menyelesaikan persoalannya, kemudian pasrah atau menyerahkan persoalannya kepada dzat yang mengaturnya. ${ }^{44}$ Jadi kita tidak boleh menyerah sebelum kita berusaha karena apabila kita tidak mencoba maka kita tidak akan akan pernah tau hasilnya. Apabila kita sudah mencoba dan ternyata gagal kita akan mendapatkan ilmu dari suatu kegagalan, dan jika kita pernah mencoba sama sekali maka kita akan tau ilmu dari suatu kegagalan tersebut. Karena tuhan memberikan suatu hikmahnya itu melalui proses kehidupan. Jika kiat tidak berproses maka hikmah tuhan tidak akan pernah sampai kekita.

\footnotetext{
${ }^{41}$ Ibid, hal.189

${ }^{42}$ Ibid, hal. 193

${ }^{43}$ Ibid, hal. 203

${ }^{44}$ Ibid, hal. 213
} 
Dari nilai-nilai karakter religus yang dituangkan Syaih Musthofa Al-Ghlayini didalam kitab Idhatun Nansyi'in ini sesuai dengan apa yang dituangkan Edy Suparjan dalam bukunya yang berjudul pendidikan sejarah untuk membentuk karakter bangsa, dimana dijelaskan didalam buku tersebut ada nilai-nilai karakter pendidikan yang mengacu pada stadart 100 tokoh ternama dunia, karakter yang ideal adalah sebagai berikut:

1. Sadar sebagai mahluk ciptaan tuhan. Sadar sebagai makhluk muncul ketika dia mampu memahami keberadaan dirinya, alam sekitar dan Tuhan YME. Konsepsi ini dibangun dari nilai-nilai transcendental.

2. Cinta tuhan. Orang sadar akan keberadaan tuhan menyakini bahwa dia tidak dapat melakukan apa pun tanpa kehendak tuhan. Oleh karenanya memunculkan rasa cinta kepada tuhan. Orang yang cinta tuhan akan menjalankan apa pun perintah dan menjauhi laranggannya.

3. Bermoral. Jujur, saling menghormati, tidak sombong, suka membantu dan sejenisnya merupakan turunan dari manusia yang bermoral.

4. Bijaksana. Karakter ini muncul karena keluasan wawasan seseorang, sehingga mampu melihat banyaknya perbedaan yang mampu diambil sebagai kekuatan.

5. Pembelajar sejati. Untuk dapat wawasan yang luas, seseorang harus senantiasa belajar. Pembelajar sejati pada dasarnya dimotovasi oleh adanya pemahaman akan luasnya ilmu tuhan.

6. Mandiri, karakter ini muncul dari penanaman nilai-nilai humanisasi dan liberalis. Dengan pemahaman bahwa setiap manusia memiliki potensi dan sama-sama menjadi subjek kehidupan maka dari itu dia tidak akan membenarkan adanya penindasan sesama manusia.

7. Kontributif, kontributif merupakan cerminan seorang pemimpin.

Dari penjelasan diatas menurut pengamatan peneliti, bahwa konsep pendidikan karakter religius dalam kitab Idhatun Nasyi'in terhadap konsep pendidikan yang di tuangkan oleh Edy Suparjan relevan. Karena konsep pendidikan karakter religius yang dituanagkan oleh Syaih Muthofa Al-ghalayaini sesuai dengan apa yang ditulias Edy Suparjan. Akan tetapi ada yang tidak relevan yaitu proses penerapan nilai-nilai tersebut, dimana proses pembelajaran Syaih Msuthofa Al-Ghalayaini masih menggunakan cara tradisonal yaitu dengan cara ceramah, yang mana peserta didik diperlukan sebagai gelas kosong yang pasif yang hanya menerima cermah dari sang guru tentang ilmu pengethauan dan informasi, sehingga ilmu pengetahuan maksimal peserta didik adalah ilmu pengetahuan yang dimiliki oleh guru saja. Sedangkan proses pembelajara yang di tulis oleh Edy Suparjan peserta didik ikut berperan aktif dalam pembelajaran, karena pengetahuan juga diambil dari pengalaman peserta didik itu sendiri. 


\section{KESIMPULAN}

Dari pembahasan yang sudah ditulis didepan, maka dapat ditarik beberapa kesimpulan:

1. Model pendidikan karakter menurut pandangan Syaih Musthofa Al-Ghalayaini merupakan usaha menanamkan akhlak terpuji dalam jiwa anak-anaka, konsep yang dibangun dari pendidikan karakter religius Syaih Musthofa Al-Ghalayaini dalam kitab Idhatun Nasyi'in, dapat dilihat dari beberapa kriteria sifat-sifat yang harus dimiliki oleh anak didik yaitu sebagai berikut: pertama, anak harus memiliki keikhlasan, kedua anak didik harus mempunyai kesabaran, ketiga anak didik harus perduli dengan sesama, keempat sebagai anak didik harus dapat memulikan dirinya sendiri terutama orang lain, kelima peserta didik harus menjalankan agamanya dengan baik, keenam sabagai perserta didik harus menepati janji, ketujuh sebagai peserta diidk harus saling tolong menolong, kedelapan sebagai peserta didik harus memiliki sifat dermawan, kesembilan peserta didik harus memiliki sifat yang positif thinking atau selalu berusaha.

2. Pendidikan karakter dalam kitab Idhatun Nasyi'in dengan konteks pendidikan karakter sekarang memiliki adanya persamaan penggunaan dan kebutuhan dengan berbagai pernyataan yang rasioanl baik tentang materi pendidikan, motede pendidikan dan tujuan pendidikan. Akan tetapi dalam proses penerapan tidak ada relevansinya. Karena Syaih Musthofa Al-Ghalayaini masih menggunakan penerapan yang trasdisional yang mana peserta didik hanya mendengarkan saja sedangkan guru lebih aktif didalam kelas. Sehingga pengetahuan peserta didik lebih sedikit dan pembelajaran menjadi monoton

\section{DAFTAR PUSTAKA}

Akhmad Muhaimin Azzel, Urgent Pendiidkan Karakter di Indonesia: Revitalisasi Pendidikan Karakter Terbadap Keberbasilan Belajar dan Kemajuan Bangsa, (Jogjakarta: Ar-Ruzz Media, 2011)

Anton Bekker, Metodologi Penelitian Filsafat, (Yogyakarta: PT.kanisius, 1990) Departemen Agama RI, AlQur" an dan Terjemahnya (Bandung: CV Penerbit Diponogoro, 2008)

Edy Suparjan, Pendidikan Sejarah Untuk Membentuk, karakter bangsa, (Yogyakarta: CV Budi Utama, 2019) Heri Gunawan, Pendidikan Karakter: Konsep Dan Implementasi, (Bandung: Penerbit Alfabet, 2014)

M. Furqan Hidayatullah, Pendidikan Karakter: Membangun Peradaban Bangsa, (Surakarta: Yuma Pustaka, 2010)

Masnur Muslich, Pendidikan Karakter (Menjawab Tantangan Krisis Multidimensional), (Jakarta: Bumi Aksara, 2011)

Mestika Zed, Metode Penelitian Kepustakaan, (Jakarta: Yayasan Obor Indonesia, 2004)

Muchlis Samami dan Hariyanto, Konsep Dan Model: Pendidikan Karakter, (Bandung: PT. Remaja Rosdakarya, 2012) 
Musthafa Al-Ghalayaini, Idhatun Nasyi'in (bimbingan Menuju Akblak Lubur) Diterjemabkan Oleh Moh. Abdai Rathomy, (Semarang: PT. Karya Toha Putra, 2002)

Permendikbud, Tentang Standard Isi Prndidikan Dasar Dan Menengah, (No.21 tahun 2016)

Samsul Nizar, Filsafat Pendidikan Islam (Pendekatan Historis, Teoritis dan Praktis), (Jakarta:Ciputat Pers, 2002)

Siswantoro, Metode Penelitian Sastra Analisis Struktur Puisi, (Yogyakarta: Rineka Cipta, 2010)

Sutrisno Hadi, Metodologi Reseach, (Yogyakarta: Yayasan Penerbitan Fakulotas Psikologi Universitas Gadjah Mada, 1980)

Wiji Astuti Ningsih, Skripsi Pendiidkan Karakter Religius Melalui Pembahasan Shalat Dzhur Berjamaah Kelas V Di SD Islam Al-Madina, (Semarang: 2016) 